\title{
Mapping a Novaculite Quarry in Hot Springs National Park
}

\section{Mary Beth D. Trubitt}

Arkansas Archeological Survey, HSU Research Station

Follow this and additional works at: https://scholarworks.sfasu.edu/ita

Part of the American Material Culture Commons, Archaeological Anthropology Commons, Environmental Studies Commons, Other American Studies Commons, Other Arts and Humanities Commons, Other History of Art, Architecture, and Archaeology Commons, and the United States History Commons

Tell us how this article helped you.

This Article is brought to you for free and open access by the Center for Regional Heritage Research at SFA ScholarWorks. It has been accepted for inclusion in Index of Texas Archaeology: Open Access Gray Literature from the Lone Star State by an authorized editor of SFA ScholarWorks. For more information, please contact cdsscholarworks@sfasu.edu. 


\section{Mapping a Novaculite Quarry in Hot Springs National Park \\ Creative Commons License \\ (c) $)(1)$ (9)}

This work is licensed under a Creative Commons Attribution-NonCommercial 4.0 International License 


\title{
Mapping a Novaculite Quarry in Hot Springs National Park
}

\author{
Mary Beth Trubitt, \\ Arkansas Archeological Survev. \\ Henderson State University Research Station, \\ Arkadelphia, Arkansas
}

\begin{abstract}
Novaculite quarries in the Ouachita Mountains of Arkansas and Oklahoma were created through largescale extraction of lithic raw materials, used for stone tools by Caddos and other Native Americans over the past 11,000 years and in recent centuries by Euro-Americans for whetstones. Quarry sites are characterized by surface features like large pits, trenches, battered boulders, and debris piles. This article summarizes the results of an Arkansas Archeological Survey research project that described and mapped surface features at one site (3GA22) to provide a better understanding of the problems and potential of documenting novaculite quarries.
\end{abstract}

\section{Introduction}

Novaculite, outcropping in the Ouachita Mountains of Arkansas and Oklahoma, has been valued as a raw material for stone tools for millennia. Ancient novaculite quarries form some of the largest archeological sites in this area, but their investigation has been hampered by their large size and scale and their inaccessible mountain ridge-top locations. The Arkansas Archeological Survey has recently completed a project with the U.S. Forest Service to create an overarching research design to guide novaculite quarries research in the Ouachita Mountains (Trubitt et al. 2004). The 2002 mapping project at 3GA22 was an offshoot of this effort, and was designed to explore techniques and methods for documenting quarry sites, as well as to clarify the site boundaries and periods of use for possible nomination to the National Register of Historic Places.

\section{Some Background on Novaculite and Novaculite Quarries}

The Arkansas Novaculite formation, made up of massive layers of novaculite and interbedded chert and shale, outcrops on ridges in the southern Ouachita Mountains along a 200 mile stretch from west of Little Rock, Arkansas, to Broken Bow, Oklahoma (Holbrook and Stone 1979). Like chert or flint, novaculite is a microcrystalline sedimentary rock formed by chemical precipitation of siliceous minerals, but Arkansas novaculite is thought to have been altered to some extent by diagenesis and metamorphosis during the formation of the Ouachita Mountains (Holbrook and Stone 1979; Keller et al. 1985; Steuart et al. 1984). Novaculite is described as "a homogenous, mostly white or light-colored rock, translucent on thin edges. with a waxy to dull luster" (Holbrook and Stone 1979:2). However, there is some variation in color, texture, and luster. Colors from white and gray to pink, red, tan, and black can be found (even at the same quarry). Texture and luster vary as well, from the hard fine-grained "Arkansas stone" to the more porous "Ouachita stone," to the weathered calcareous novaculite or tripoli (Griswold 1892:57-58 89-95, 103: Holbrook and Stone 1979:4-5). The translucency of 
novaculite is often used as a sorting criterion (Jeter and Jackson 1994:160) but translucency is related to texture and varies in novaculite (Luedtke 1992:69 and Appendix B).

Chipped stone tools made from Arkansas Novaculite are ubiquitous on archeological sites in the Ouachita Mountains and adjacent areas of the Gulf Coastal Plain in southwest Arkansas and southeast Oklahoma (e.g., Early 1988; Schambach 1998; Waddell et al. 1995: Wyckoff 1968). As Holmes (1891:313) expansively described: "..hundreds of square miles are strewn with flakes, fragments, failures and rejected pieces lof novaculitel, and the country around, from the mountains to the gulf, is dotted with the finished forms that have been used and lost." In the mountains, novaculite could be procured directly from outerops, from surfaces of talus slopes below outcrops, and in the form of cobbles from riverbed gravels (Coleman et al. 2000; Martin 1982; Waddell et al. 1995). Away from the Ouachita Mountains in southem Arkansas, eastern Oklahoma, and northeastern Texas, novaculite could be obtained either from riverbed cobbles from the rivers flowing out of the mountains or from gravel deposits in Pleistocene terraces. Novaculite could have also been procured from outcrops back in the Ouachitas and transported directly or traded into these regions (Hemmings 1982: Perino and Bennett 1978; Perttula 1984; Waddell and King 1990).

In west-central Arkansas, the use of novaculite spans the range of prehistoric periods (e.g., Schambach 1998). There is some evidence that the heaviest use was during the Archaic period (e.g., Baker 1974:28-29), perhaps as novaculite became part of the Late Archaic period Poverty Point exchange system (Jeter and Jackson 1994). Different regions show different temporal trends, however. In the Felsenthal region (Ouachita River valley in southern Arkansas), novaculite use was higher during pre-Mississippian periods than during the Mississippian period (Hemmings 1982:242-244: Kelley 1984). But in a study of Lake Fork Reservoir sites in northeastern Texas, non-local lithics (including novaculite) had low frequencies in Archaic period assemblages and higher frequencies in Caddo contexts (Pertula 1984:137-139). In Hot Springs, Arkansas, quarrying novaculite for whetstones became an important local industry early in the nineteenth century and continued during the twentieth century (Griswold 1892; Whittington 1969). Novaculite and tripoli are still being mined commercially today (Steuart et al. 1984).

Nineteenth-century descriptions of novaculite quarries (Featherstonhaugh 1968[1844]:110-111; Griswold 1892:175-176; Holmes 1891, 1974[19197:196-200; Jenney 1891) linked their use to the Indians previously living in the region and noted evidence of novaculite tool manufacture at habitation sites in the area. W. H. Holmes (1974) used novaculite quarries as examples in his treatise on aboriginal stone quarrying in North America. Only brief descriptions appeared in the literature in the mid-twentieth century (Lemley 1942; Whittington 1969).

More recent archeological investigation of novaculite quarries and workshop sites has focused on recording new sites and examining the spatial distribution of novaculite tool-working activities. A 1973 reconnaissunce of Hot Springs National Park by the Arkansas Archeological Survey recorded several new novaculite quarry and tool manufacturing sites (Baker 1974. 1982). As part of his thesis research, Baker (1974, 1982) also conducted limited test excavations at a quarry site near Magnet Cove (3GA48/3HS 158/3HS433). Recent surveys of U.S. Forest Service lands have recorded numerous quarry sites and examined the patterning of novaculite reduction activities across the landscape (e.g., Waddell and Waddell 1992; Waddell et al. 1995; Williams ef al. 1993). Forest Service archeologists have been actively documenting novaculite quarry and workshop sites. Etchieson (1997) describes the types of large-scale features found at quarry sites, including pits and trenches, battered boulders and outerops, artificial benches created by surface stripping to expose novaculite, shelters or caves enlarged by quarrying novaculite, and trails to quarries. Colentan's (2003) analysis of the lithic assemblage from test excavations at a Middle Archaic period novaculte workshop site investigated ideas about humtergatherer mobility patterns and technological organization. During the Arkansas Archeological Survey/Arkansas Archeological Society training program at Shady Lake in 1993, a novaculite quarry site (3PL.349) was mapped 
and tested (Coleman et al. 1999. Hilliard 1995). A more detailed analysis of the novaculte debitage from these excavations is currently underway at the Survey's Henderson Research Station.

\section{Previous Research at 3GA22}

Site 3GA22, a novaculite quarry in Arkansas's Hor Springs National Park, has been known to the archeological community for over 100 years. W. H. Holmes (1891:314) described the ste as "a number of pits and excavations dug in and about the crest of the ridge. This ridge is a solid formation of the novaculite weathering out in irregular grayish flinty-looking masses which protrude from the crest or project on the slopes, forming short broken cliffs from ten to twenty feet in height." Two of the largest pits, one about 150 $\mathrm{ft}$. (ca. $46 \mathrm{~m}$ ) in diameter and $25 \mathrm{ft}$. (ca. $8 \mathrm{~m}$ ) deep, the other larger but shallower, were formed by quarrying a novaculite outcrop downwards from the surface and discarding debris from knapping blanks around the pit edges (Holmes [1974:Figure 77] marked these pits "D" and "C" on his map, shown here as Figure 1). Holmes (1891) hypothesized that fire was used for quarrying, based on his observance of "blackened patches" on some undercuts (Holmes 1891:315). Quantities of knapping debris were seen around the pits and on level areas of the ridgetop (the "Great Workshop"), and Holmes (1891:315 and Plate III) also hypothesized that bifacial blanks and preforms were taken from the quarries to be finished into tools at other sites. He notes some evidence of recent disturbance at the site by people searching for old Spanish gold mines, but writes: "That the recent work has not seriously changed the contour of the ancient quarries is evident from the fact that the entire mass of ejected material, interior and exterior, is composed of the partially shaped fragments derived from ancient flaking" (Holmes 1891:315).

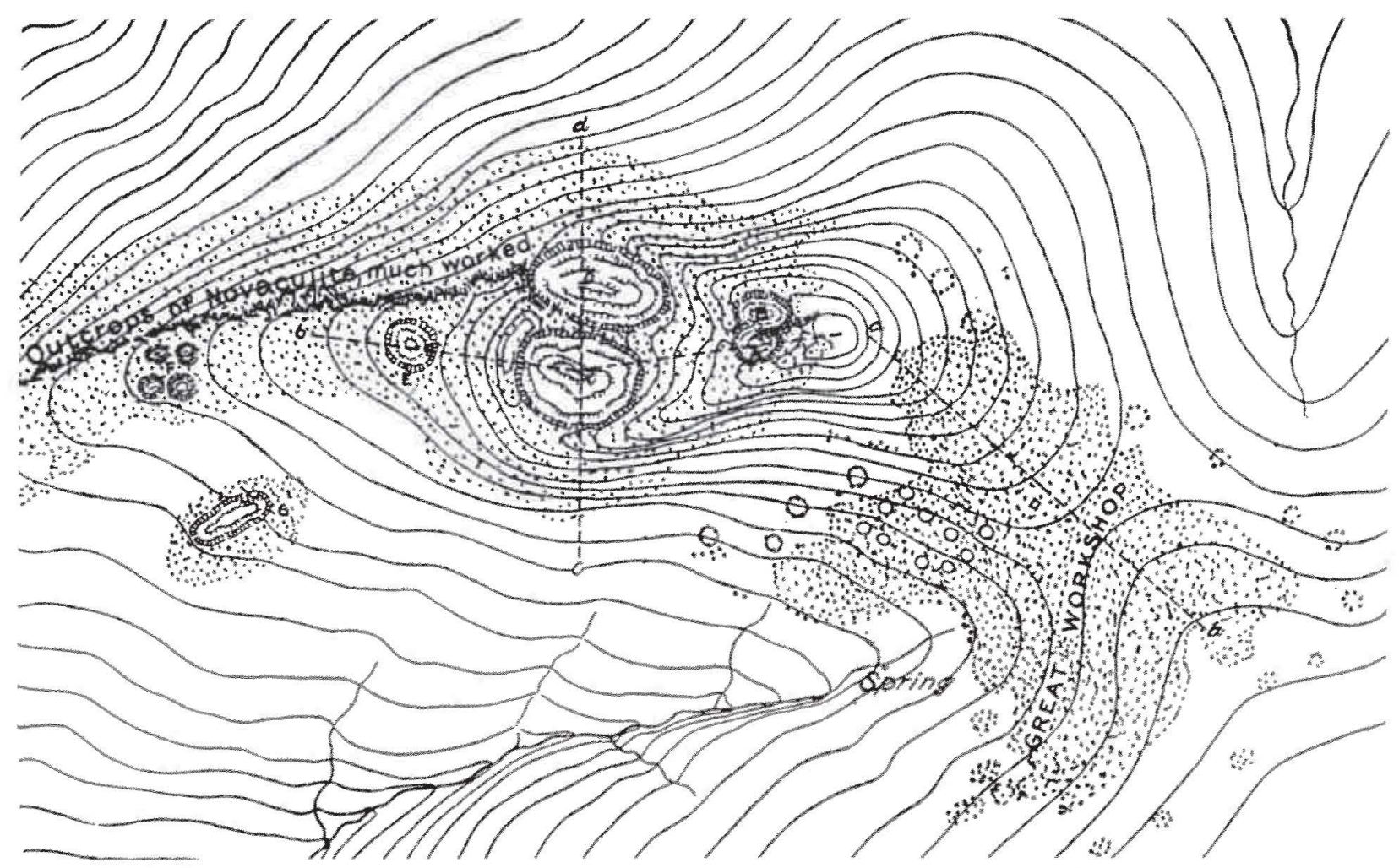

Figure 1. W. H. Holmes's map of the main quarrying area at 3GA23 (Holmes 1974: Figure 77 ). 
Following visits to the site by local amateur archeologist Forest Sargent (1966), 3GA22 was recorded in the state site files in 1969 by Sargent and James Scholtz. Collections made at that time included hammerstones, novaculite debris, and worked pieces of novaculite (AAS/HSU Accession 69-40, 70-655). The presence of nearby abandoned whetstone quarries was noted. Baker (1974, 1982) revisited the site during his master's thesis research in 1973. He relocated Holmes' "Great Workshop" and the novaculite "ledge" and quarry pits (Baker 1974:Figure 1), and extended the site boundaries on the eastern side with the addition of seven quarry pits, about 2-4 $\mathrm{m}$ in diameter and 1-2 $\mathrm{m}$ deep with "chipping debris, tool blanks, and hammerstones" around them, scattered over an approximately 3 acre area (Baker 1974:11; 3GA22 site form; this area was originally designated as $3 \mathrm{GA} 46$ but is now included in $3 \mathrm{GA} 22$ ).

The novaculite source on this mountain has provided raw material samples for published novaculite heat treatment experiments. Flenniken and Garrison (1975) used a large piece of white novaculite to make bifaces and then heated them to $200^{\circ} \mathrm{C}, 450^{\circ} \mathrm{C}$, and $500^{\circ} \mathrm{C}\left(392^{\circ} \mathrm{F}, 842^{\circ} \mathrm{F}\right.$, and $\left.932^{\circ} \mathrm{F}\right)$. No change was seen at $200^{\circ} \mathrm{C}$, but the $450-500^{\circ} \mathrm{C}$ samples showed a change in microscopic texture that resulted in a glossy appearance and improvement in knapping characteristics. Sollberger (in Bennett 1986:69-73) found that pieces of white novaculite showed a change to a pink or red color with an increase in luster, along with an increase in workability, when heated to $620^{\circ} \mathrm{F}\left(327^{\circ} \mathrm{C}\right)$. It should be noted that a wide range of novaculite colors can be seen in debris at $3 \mathrm{GA} 22$, but it is not clear whether this range reflects natural variation of the outcrops or the use of heat treatment.

There are archeological sites further east of 3GA22 along the mountain ridge (3GA47, 3GA135, 3GA138, 3GA141, and 3GA832-840) that have evidence of aboriginal quarrying in the form of shallow pits and trenches and scatters of chipping debris. In addition, there are unrecorded sites that reflect the nineteenth and twentieth century mining of novaculite for whetstone raw material (Griswold 1892:308; Whittington 1969:228). One of the companies operating in this area was Arkansas Abrasives, Inc., managed by Frank Thompson, which marketed a line of whetstones beginning in the 1950s and expanded into industrial abrasives and novaculite finishing media, later doing business as Buffalo Stone Corporation (Ms. Mary Little, 2002 personal communication; Mrs. Frank Thompson, 2002 personal communication). The overlapping of ancient quarry features by more recent activity at novaculite outcrops is typical of the Hot Springs region; nineteenth and twentieth century quarrymen often found and collected hammerstones during their work, and they likely started their operations in or near ancient quarries.

Recently, Mark Blaeuer (1995) of the National Park Service prepared a draft National Register of Historic Places nomination for $3 \mathrm{GA} 22$. Two issues raised during this process were the need to clarify the boundaries of the site and the need for more information on the periods of use of the site. The 2002 mapping project at $3 \mathrm{GA} 22$ was intended to contribute information for the first of these issues by describing and mapping surface features.

\section{The 2002 Mapping Project: Methods and Results}

New research at 3 GA22 was designed to map the cultural features associated with novaculite quarrying activities in an effort to refine the site boundaries and to test techniques and methods for researching this kind of large-scale lithic extraction site. Creating measured maps of quarry sites that indicate cultural features such as battered outcrops and boulders, quarry pits, and debris scatters, is the first step in assessing and comparing the scale and types of lithic extraction and procurement activities, as Hatch (1994) has shown for jasper quarries in Pennsylvania. 
The mapping project at 3GA22 was done under an Archaeological Resources Protection Act permit (MWR02-1) obtained through the Hot Springs National Park and the National Park Service's Midwest Archeological Center. The field work took place over six days between February 15th and March 8th, 2002. Field personnel included Mary Beth Trubitt and Kate Wright (Arkansas Archeological Survey), assisted by Harry Hammond, Mary Little, Mildred Grissom, and Patricia Heacock (Arkansas Archeological Society, Ouachita Chapter), and Michael Head and Jeffrey Gaskin (students from Henderson State University). Mapping was done with a combination of techniques and equipment, including an electronic total station (Topcon GTS-211D) with stadia/target, a hand-held global positioning system unit (Garmin eTrex Vista), and standard metric tape measures. After field work, maps were produced using Golden Software's Surfer program and Maptech's Terrain Navigator software. A final report was prepared and submitted to the National Park Service (Trubitt 2003).

Several logistical problems were encountered during field work. Visibility for topographic mapping in a wooded environment and identification of surface features was maximized by scheduling the field work for the late winter/early spring before trees and vines fully leafed out. Site accessibility was a factor, as equipment had to be carried from the vehicle up about $300 \mathrm{ft}$. of elevation to the site. A backpack for the total station and multiple crew members made it possible to carry equipment up the mountain. Another factor was the size of the site. While a total station has a much greater useful range than a transit in open areas, trees and rough terrain made multiple setups or mapping stations necessary. Topographic mapping only included the area of the site covered by the Holmes map. Outcrops further west, and areas of modern quarrying to the south and east, were plotted on a digital quad sheet using the GPS unit. In addition, the novaculite outcrops on the site's northwest side presented mapping hurdles because the irregular and steep topography was difficult to access with equipment in the field and difficult to portray using the mapping software. Finally, differentiating between the older pits from Native American toolstone procurement activities and newer pits from Euro-American whetstone mining activities can be problematic. In the absence of archival research, detectable surface artifacts such as hammerstones or metal quarry tools, or excavations to identify characteristic debitage, I used rectangularity and steepness of pit sides as an indicator of modern quarry features, or features modified by nineteenth and twentieth century whetstone quarrying.

Points taken with the GPS unit indicate the more ancient and more recent quarry features of 3 GA22 extend about $1000 \mathrm{~m}$ along two ridges on the mountain between about $800-1100$ feet amsl. A total of 18 quarry pits or trenches were plotted along the southern ridge; based on steepness of pit sides, square or rectangular outlines, and proximity to an old access road, these are identified as nineteenth and/or twentieth century features. Additional pits may be identified with more field survey. Examining the associated debris would give a more conclusive interpretation of period of use (some have flakes in the debris piles and may have overlapping ancient and modern use).

An area of about $250 \mathrm{~m}$ north-south $\times 200 \mathrm{~m}$ east-west corresponds to the main area of 3GA22 used for novaculite toolstone quarrying, as indicated by surface flaking debris, shallow to deep circular quarry pits, and worked/battered novaculite outcrops. In addition to GPS point plotting, this area was mapped topographically using the total station (Figure 2), and corresponds to the area mapped previously by Holmes (see Figure 1). A total of 11 quarry features was identified in this area (Table 1$)$. Most are pits or trenches ( $F-2,3,4,5,6,8.9$. $10,11)$, one is a concentrated area of debris on the surface (F-1. Holmes" "Great Workshop"), and one is an outcrop with evidence of working (F-7). The quarry features are concentrated on the northern ridge. Features on the southern ridge include a shallow oval quarry pit (F-4) that is thought to be from toolstone quarrying, two depressions (F-10.11) that appear to be from more recent whetstone quarrying (or older pits with more recent disturbances), and a small depression (F-9) that may be either a quarry feature or a large tree fall. In a flat saddle between the two ridges is an extensive area covered with chipping debris ( $\mathrm{F}-1)$. 


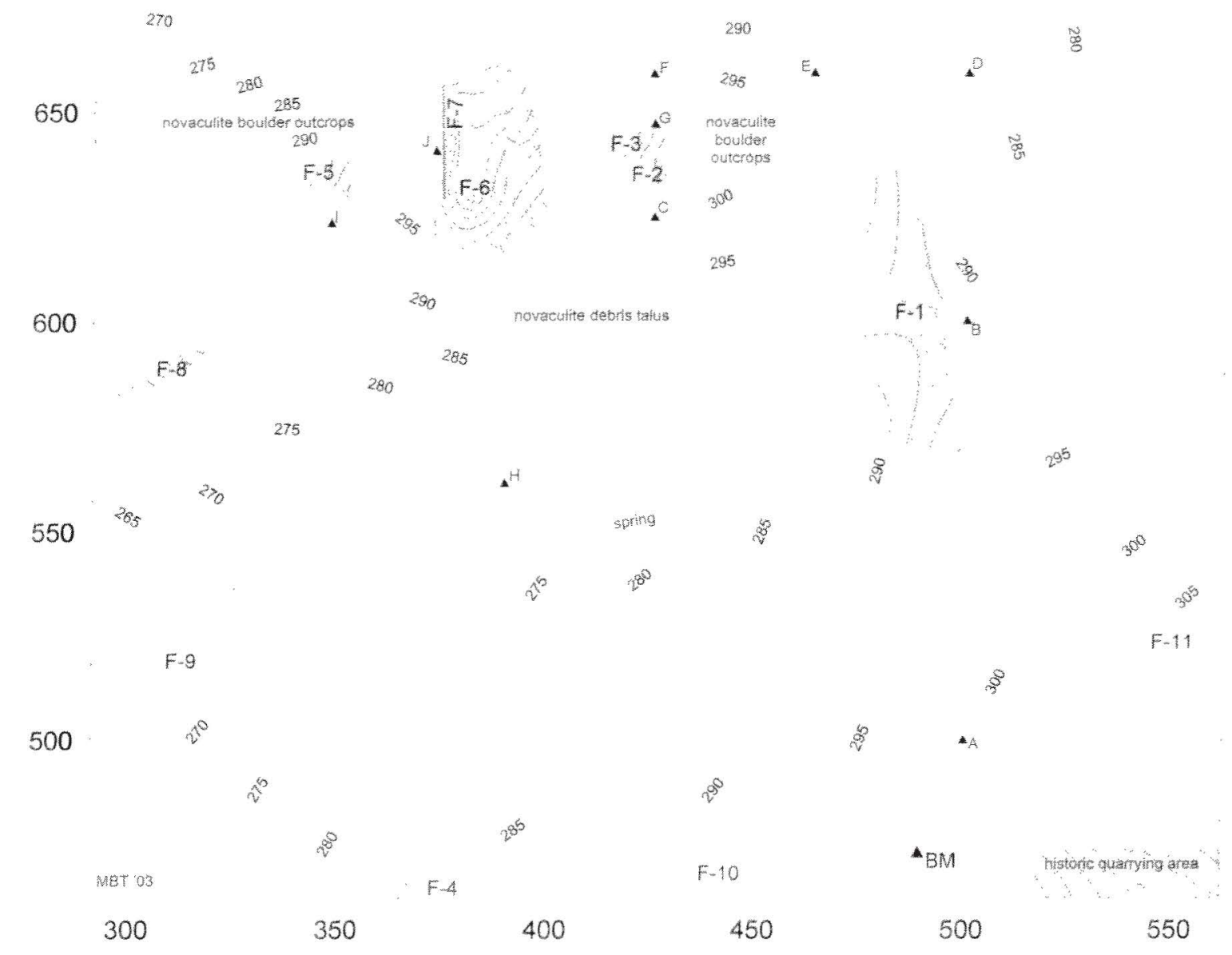

Figure 2. New topographic map of 3 GA22 showing locations of surface features and mapping stations.

A 'spring' is shown on the Holmes map and was mapped in 2002 as well. There was some water found in the bottom of this gully during our field work in February-March, but none at the time of a July site visit, so this may be seasonal water drainage rather than a perennial spring. Ancient quarry workers may have preferred novaculite outcrops with nearby springs or seeps, since working on a mountaintop for any length of time would require water (carried up or accessible nearby). Springs have been noted near other novaculite quarries visited in the Ouachita Mountains, and I suspect that this is not coincidental.

Feature 1, Holmes" "Great Workshop," is a large sprawl of novaculite debris in the saddle of flatter land between the ridges and gullies. This area is literally covered with novaculite debitage, highly visible because of its density and a recently re-cut right-of-way access road. The F- 1 boundaries approximate the area of heaviest exposed debris (novaculite flakes and shatter, as well as chipped novaculite bifaces/fragments and sandstone hammerstones/fragments), and novaculite continues beyond this on the surface. During our field work. We mapped and described (but did not collect) a total of 17 sandstone hammerstones or fragments and one novaculite dart point (Table 2). The hammerstones are made of a raw material that is not found on the ridgetop formation but was transported from lower elevations. The dart point, the only diagnostic identified during the field work. is typed as a Fourche Malne period Gary, war. LeFbore/Bodcon point (Schambach 1998:58-59, 118-121). 
Table 1. Surface Quarry Fatures, 36A22.

\begin{tabular}{|c|c|c|c|}
\hline Fea.H & Description & $\underline{\text { Size }}$ & $\frac{\text { Holmes }}{\text { Designation }}$ \\
\hline 1 & $\begin{array}{l}\text { surface scatter of quarry/workshop } \\
\text { debris }\end{array}$ & $\begin{array}{l}\text { area of greatest } \\
\text { concentration: } \\
20 \mathrm{~m} \mathrm{E}-\mathrm{W} \times 70 \mathrm{~m} \mathrm{~N}-\mathrm{S}\end{array}$ & Great Workshop \\
\hline 2 & oval quarry pit & $7 \times 10 \mathrm{~m}, 1.5 \mathrm{~m}$ deep & A \\
\hline 3 & oval quarry pit & $12 \times 18 \mathrm{~m}, 3 \mathrm{~m}$ deep & B \\
\hline 4 & oval quarry pit & $4.5 \times 7.5 \mathrm{~m}, 0.5 \mathrm{~m}$ deep & \\
\hline 5 & circular quarry pit & $15 \times 16.5 \mathrm{~m}, 2.5 \mathrm{~m}$ deep & $\mathrm{E}$ \\
\hline 6 & $\begin{array}{l}\text { large oval quarry pit with } 2 \text { interior } \\
\text { debris piles }\end{array}$ & $30 \times 46 \mathrm{~m}, 5 \mathrm{~m}$ deep & $\mathrm{C}, \mathrm{D}$ \\
\hline 7 & quarried outcrop exposed by F-6 & $\begin{array}{l}26 \mathrm{~m}(\mathrm{~N}-\mathrm{S}) .4 .7 \mathrm{~m} \max . \\
\text { height }\end{array}$ & \\
\hline 8 & $\begin{array}{l}\text { linear depression into side of ridge, } \\
\text { quarry trench? }\end{array}$ & $7 \times 10 \mathrm{~m}, 1 \mathrm{~m}$ deep & $\mathrm{G}$ \\
\hline 9 & possible quarry pit (or tree fall) & $2 \times 3 \mathrm{~m}, 0.5 \mathrm{~m}$ deep & \\
\hline 10 & $\begin{array}{l}\text { oval/rectangular quarry trench, } \\
\text { recent or recent disturbance to old } \\
\text { feature? }\end{array}$ & $5 \times 9 \mathrm{~m}, 1.5 \mathrm{~m}$ deep & \\
\hline 11 & $\begin{array}{l}\text { small rectangular quarry trench, } \\
\text { recent? }\end{array}$ & $1 \times 2 \mathrm{~m}, 0.5 \mathrm{~m}$ deep & \\
\hline
\end{tabular}

The main area of quarrying on the nothern ridge (Figure 3) has several distinct pits ( F-2.3, and 5. Figure 4), a large pit filled with piles of debris (F-6. Figure 5), and adjacent exposed outcrop (F-7, Figure 6). The adjacent oval pits labeled F-2 and F-3 (Figures 7 and 8 ) are separated by a line of large novaculite boulders that appears to be the surface of a novaculite outcrop left in place while adjacent seams were quarried out. A scatter of novaculite boulders lie on the surface of the ridge just east of these two pits. The F-6 pit and F-7 outcrop area (see Figures 3,5-6) is a large feature complex created by quarrying to expose a seam of high-quality toolstone visible at the base of the outcrop (Baker 1974:10 11). Some debris from this quarrying was left in piles within F-6 while other debris forms an extensive talus slope on the south side of the ridge.

It is clear that the northern ridge was extensively remodeled by the quarrying and knapping activities that took place here in the past. A three-dimensional view of the northern ridge (Figure 9) shows that so much novaculite was removed that over $50 \mathrm{~m}$ of the ridge crest has been obliterated. Presumably this activity took place over the span of thousands of years. The one diagnostic recorded during this field work suggests use at least during the Fourche Maline period (ca. 650 B.C. - A.D. 950). Dating the use of this complex of quarry features remains as a major research question for this site. and may be answerable through excavation. 
Table 2. Artifacts Piece-Plotted on Surface, F-1, 3GA22.

\begin{tabular}{|c|c|c|c|c|}
\hline \multicolumn{5}{|c|}{ Hammerstones: } \\
\hline$\frac{A r t .}{\#}$ & Material & Description & $\underline{\text { Size }}$ & $\underline{\text { Weight }}$ \\
\hline 1 & sandstone & battered, rounded, with one flat surface & $9.5 \times 8 \mathrm{~cm}$ & $1012 \mathrm{~g}$ \\
\hline 2 & sandstone & very battered, square & $9.5 \times 8.5 \mathrm{~cm}$ & $632 \mathrm{~g}$ \\
\hline 3 & sandstone & battered, square & $10.5 \times 9.5 \mathrm{~cm}$ & $942 \mathrm{~g}$ \\
\hline 4 & sandstone & battered, round with pitting & $9 \times 8.5 \mathrm{~cm}$ & $566 \mathrm{~g}$ \\
\hline 5 & sandstone & $\begin{array}{l}\text { battered, pitted round fragment, some flat } \\
\text { surfaces }\end{array}$ & $7 \times 6 \mathrm{~cm}$ & $186 \mathrm{~g}$ \\
\hline 6 & sandstone & battered round cobble fragment & $6 \times 6 \mathrm{~cm}$ & $146 \mathrm{~g}$ \\
\hline 7 & sandstone & battered round cobble fragment & $11.5 \times 7 \mathrm{~cm}$ & $592 \mathrm{~g}$ \\
\hline 8 & sandstone & battered round cobble fragment & $7.5 \times 7 \mathrm{~cm}$ & $186 \mathrm{~g}$ \\
\hline 9 & sandstone & battered round cobble fragment & $8.5 \times 7.5 \mathrm{~cm}$ & $280 \mathrm{~g}$ \\
\hline 10 & sandstone & battered round cobble fragment & $13 \times 10 \mathrm{~cm}$ & $762 \mathrm{~g}$ \\
\hline 11 & sandstone & battered round cobble fragment & $9 \times 7 \mathrm{~cm}$ & $300 \mathrm{~g}$ \\
\hline 12 & $\begin{array}{l}\text { sandstone } \\
\text { with } \\
\text { quartzite }\end{array}$ & battered round cobble fragment & $8.5 \times 8.5 \mathrm{~cm}$ & $488 \mathrm{~g}$ \\
\hline 13 & sandstone & flat, battered on ends & $18 \times 17.5 \mathrm{~cm}$ & $1814 \mathrm{~g}$ \\
\hline 14 & sandstone & very battered, very rounded & $7 \times 7 \mathrm{~cm}$ & $450 \mathrm{~g}$ \\
\hline 15 & sandstone & very battered and rounded & $9 \times 7 \mathrm{~cm}$ & $436 \mathrm{~g}$ \\
\hline 16 & sandstone & battered round cobble fragment & $8 \times 6 \mathrm{~cm}$ & $132 \mathrm{~g}$ \\
\hline 17 & sandstone & battered rounded cobble fragment & $10 \times 8 \mathrm{~cm}$ & $340 \mathrm{~g}$ \\
\hline \multicolumn{5}{|c|}{ Dart Point: } \\
\hline$\frac{A r t .}{\#}$ & Material & Description & $\underline{\text { Size }}$ & Weight \\
\hline 18 & $\begin{array}{l}\text { novaculite, } \\
\text { white/gray }\end{array}$ & $\begin{array}{l}\text { contracting-stemmed point or late stage } \\
\text { preform, beveled, no resharpening } \\
\text { apparent; similar to type Gary, var. } \\
\text { LeFlore/Bodcaw }\end{array}$ & $\begin{array}{l}\text { L } 6 \mathrm{~cm} \\
W 3.5 \mathrm{~cm} \\
\text { Th } 1 \mathrm{~cm}\end{array}$ & NA \\
\hline
\end{tabular}




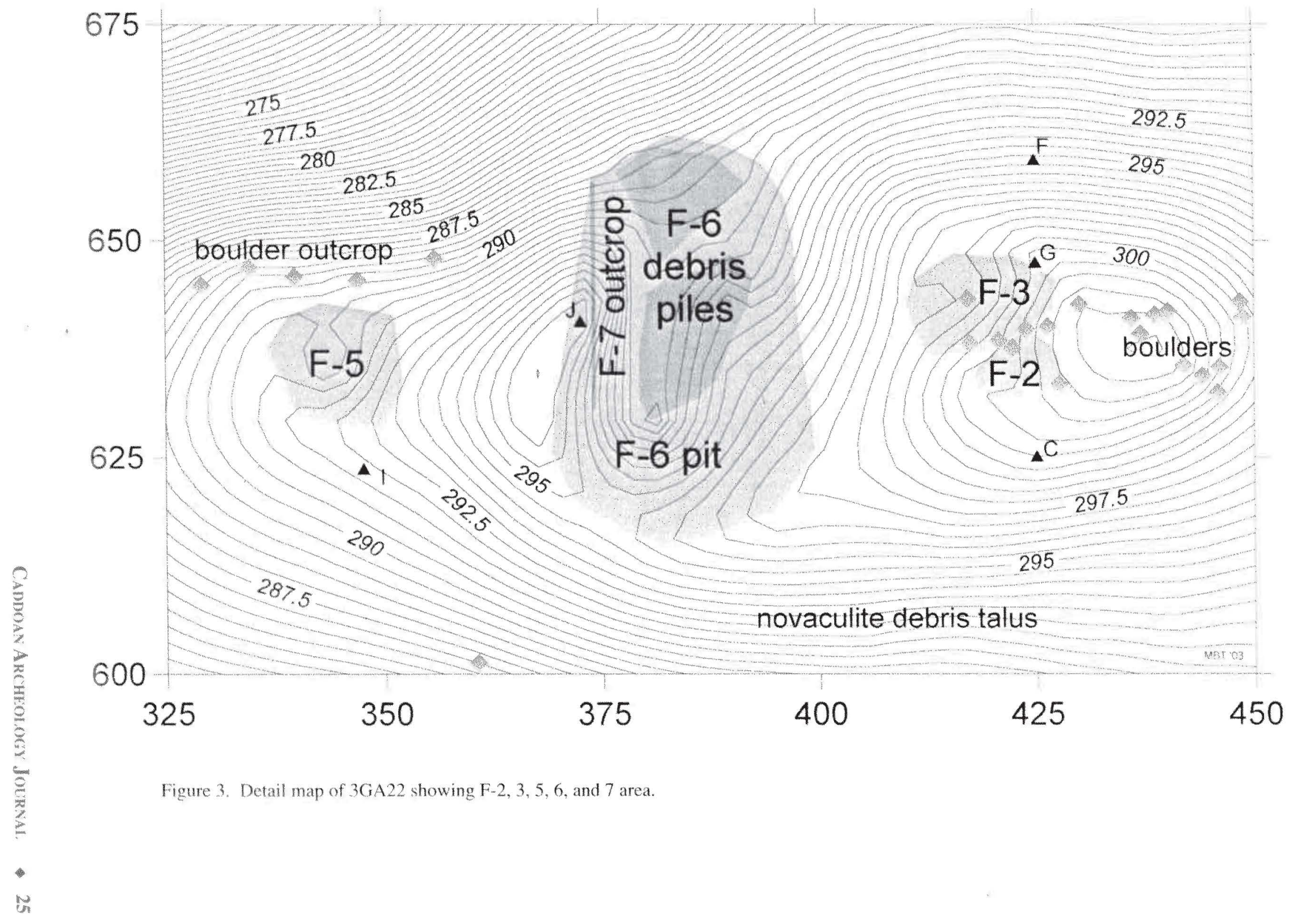




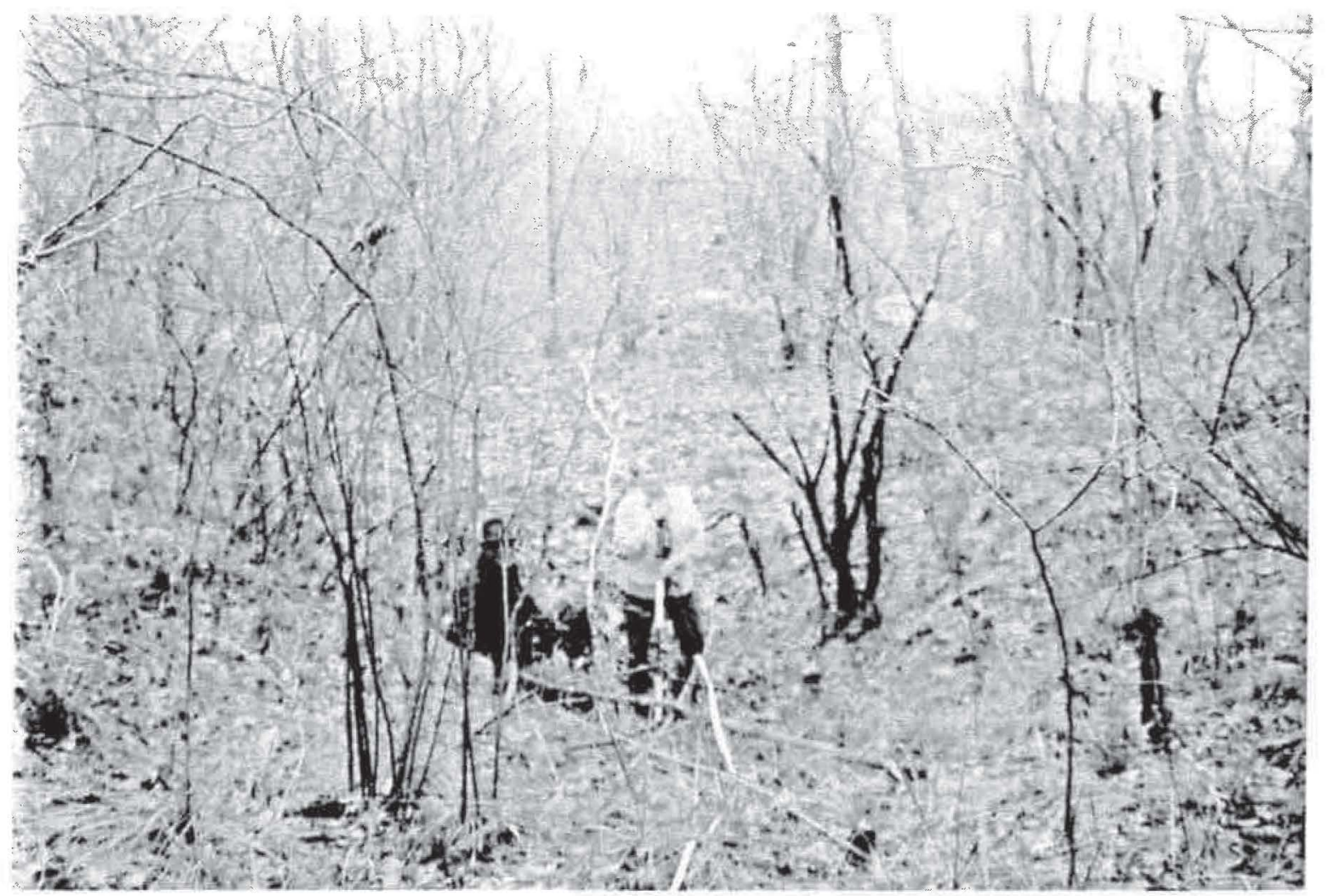

Figure 4. Mapping quarry pit F-5, facing north (AAS/HSU slide 10435).

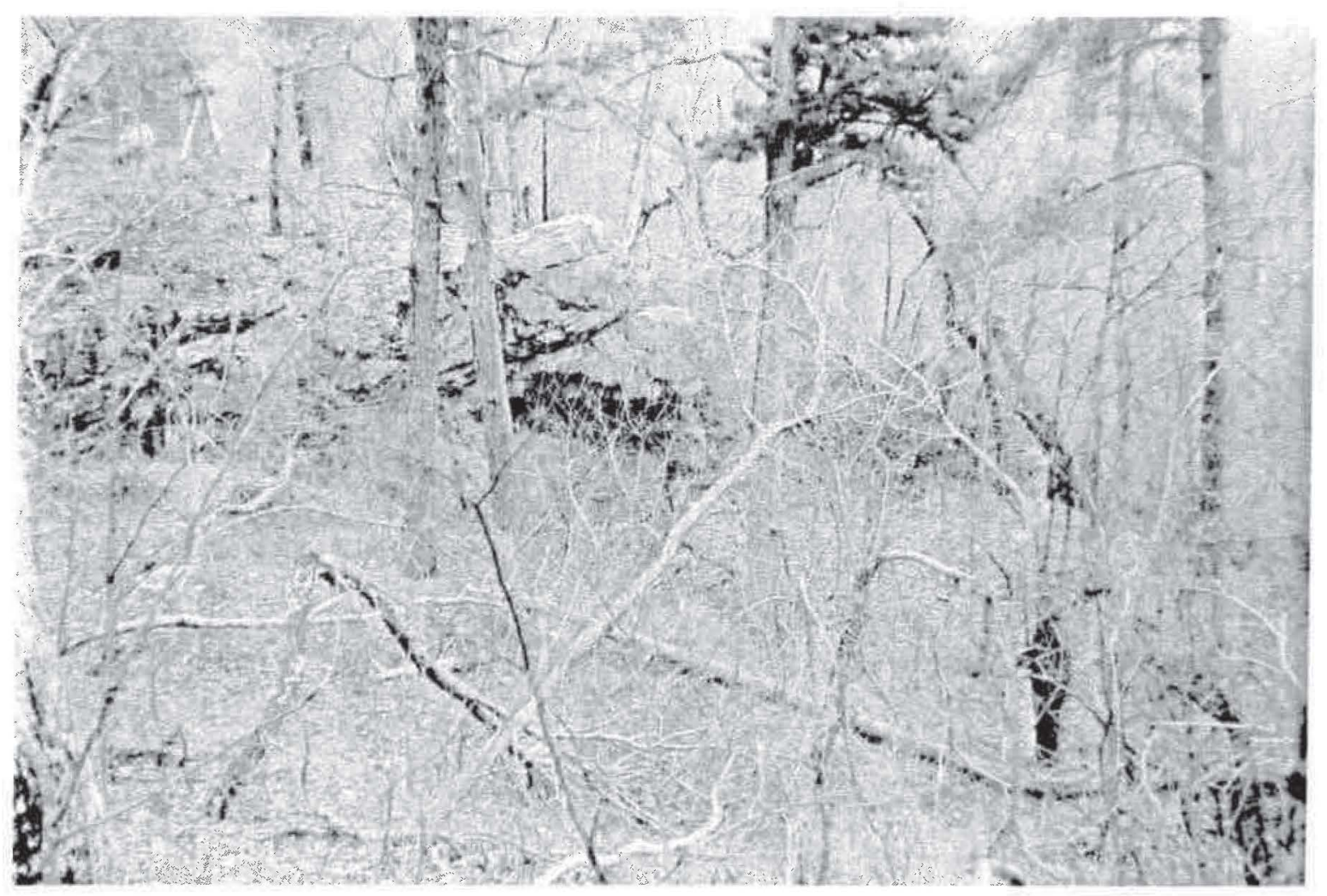

Figure 5. Mapping quarry pit F-6. with total station set on top of novaculite outcrop F-7, facing west (AAS/HSU slide 10439$)$. 


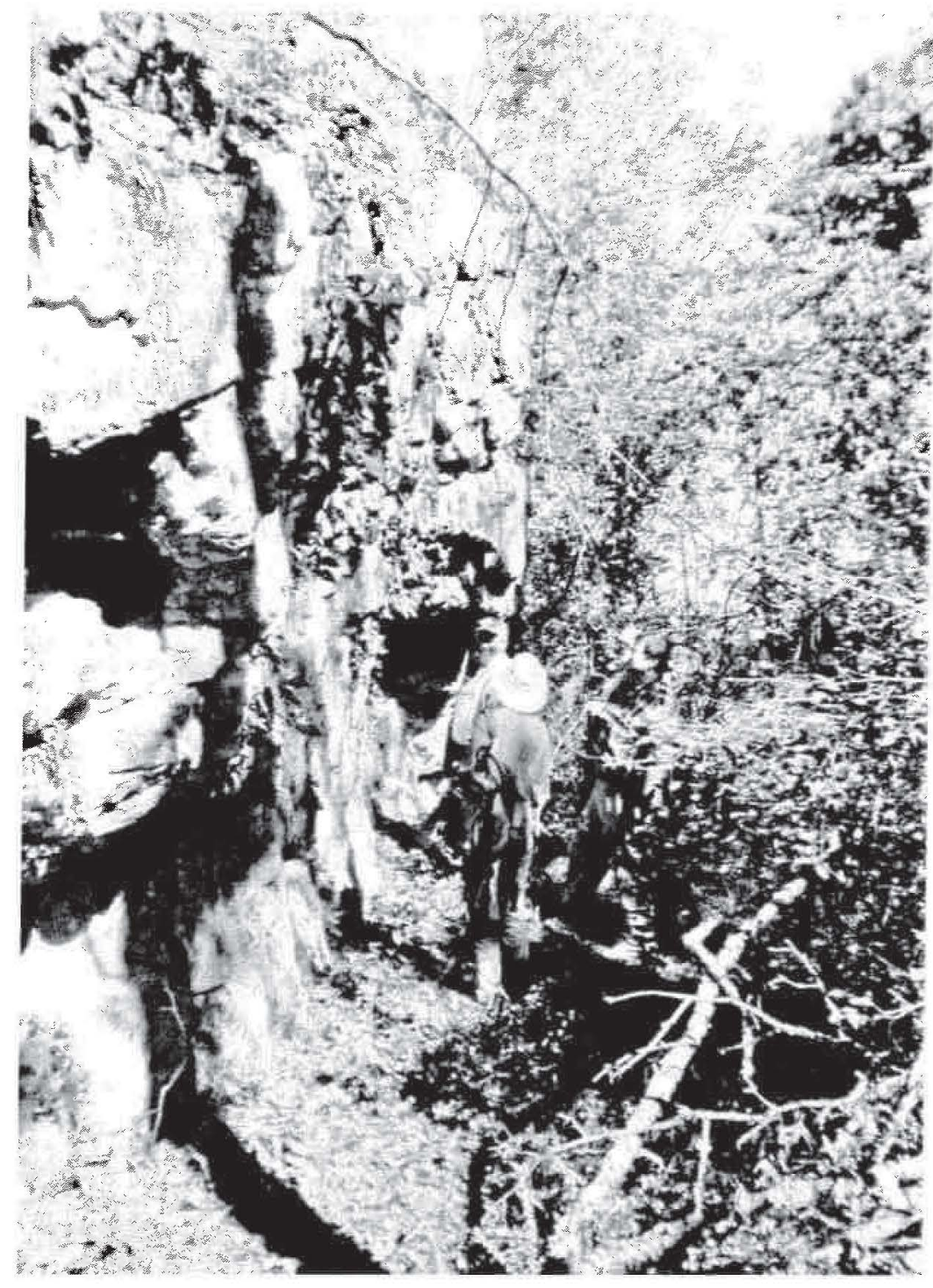

Figure 6. Novaculite outcrop F-7, facing north (AAS/HSU slide 10182),
Conclusions

Novaculite quarries are a major site type in the Ouachita Mountains, and one that presents numerous logistic and methodological problems as well as great potential for investigating past human activities in this region. There are certainly 10 gistical problems to deal with when researching these large mountaintop quarry sites. Tree foliage limits visibility of surface features, so surveying during late winter/early spring is optimal for visibility and weather conditions.

The size and scale and rugged terrain of novaculite quarries makes mapping these sites more difficult. Three mapping methods were used during this project. Plotting GPS points taken at quarry features provided an indication of the extent of the site and its location on the geological quadrangle map. but not at sufficiently large scale to show details of the site or its features. Higher resolution global positioning system units could be used for more detailed site mapping. A topographic map was created of the main quarry

feature area using a total station. In conjunction with this, more detailed sketch maps of individual quarry pits were made using standard tape measures. These techniques showed the relationships between features and between features and the landscape. However, novaculite outcrops with extreme topographic variation proved difficult to show on the maps produced, and the more detailed mapping was time-consuming.

After the field work was done, several kinds of aerial photographs of Hot Springs National Park were examined. While exposed novaculite in the modem quarries shows up strongly against the wooded vegetation of adjacent areas, the smaller exposures, such as the $\mathrm{F}-2,3,5,6$, and 7 complex mapped at $3 \mathrm{GA} 22$, were not visible. In the future it may be worthwhile to use a combination of high resolution aerial photographs and more accurate GPS technology to generate large-scale maps that focus on the locations and situation of cultural features. Since quarry features are often scattered over large areas, detailed topographic mapping using a total station might focus on configurations of the features themselves (quarry pits, talus slopes of debris, workshop areas). 


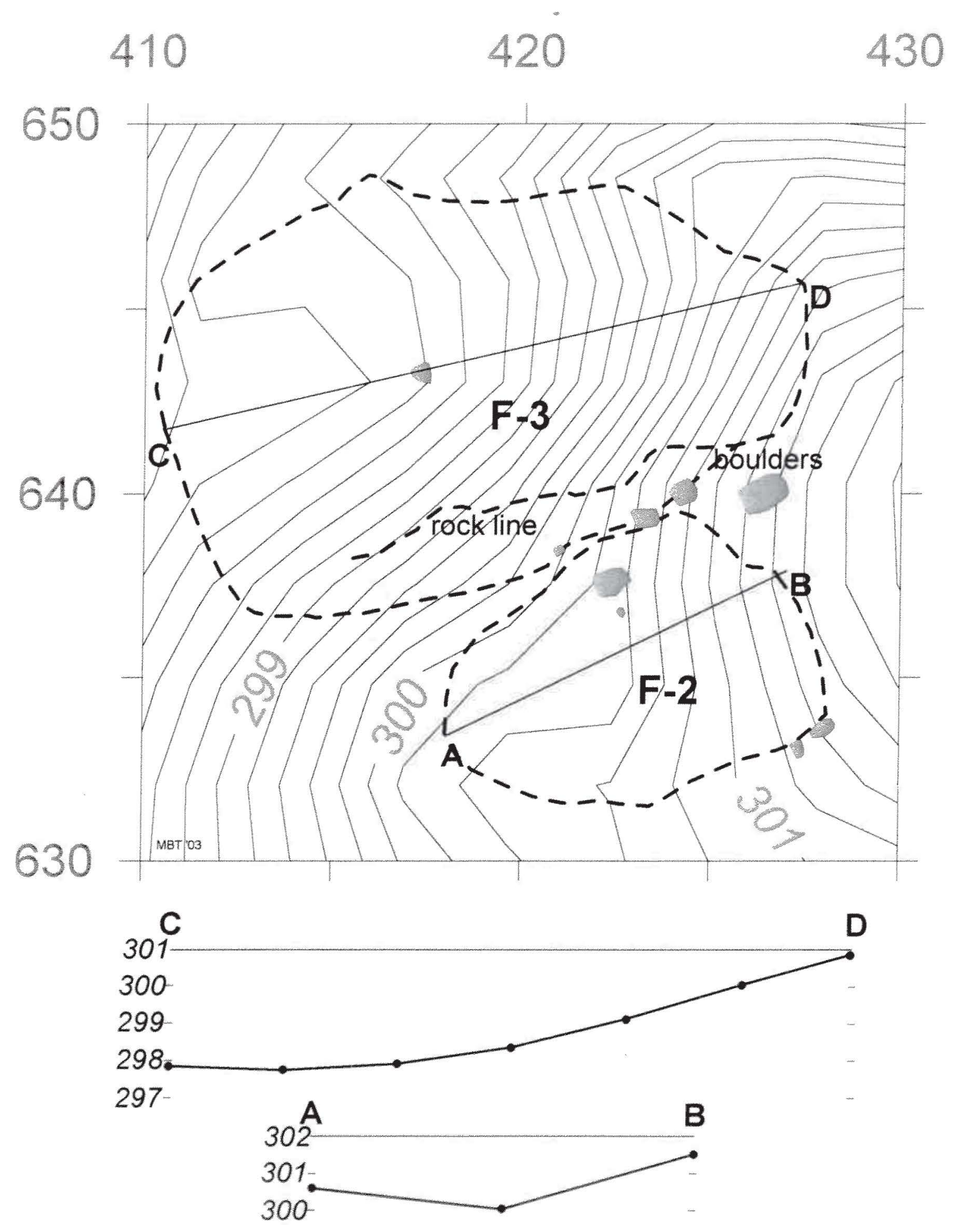

Figure 7. Detail plan and cross-sections of quarry pits F-2 and F-3. 


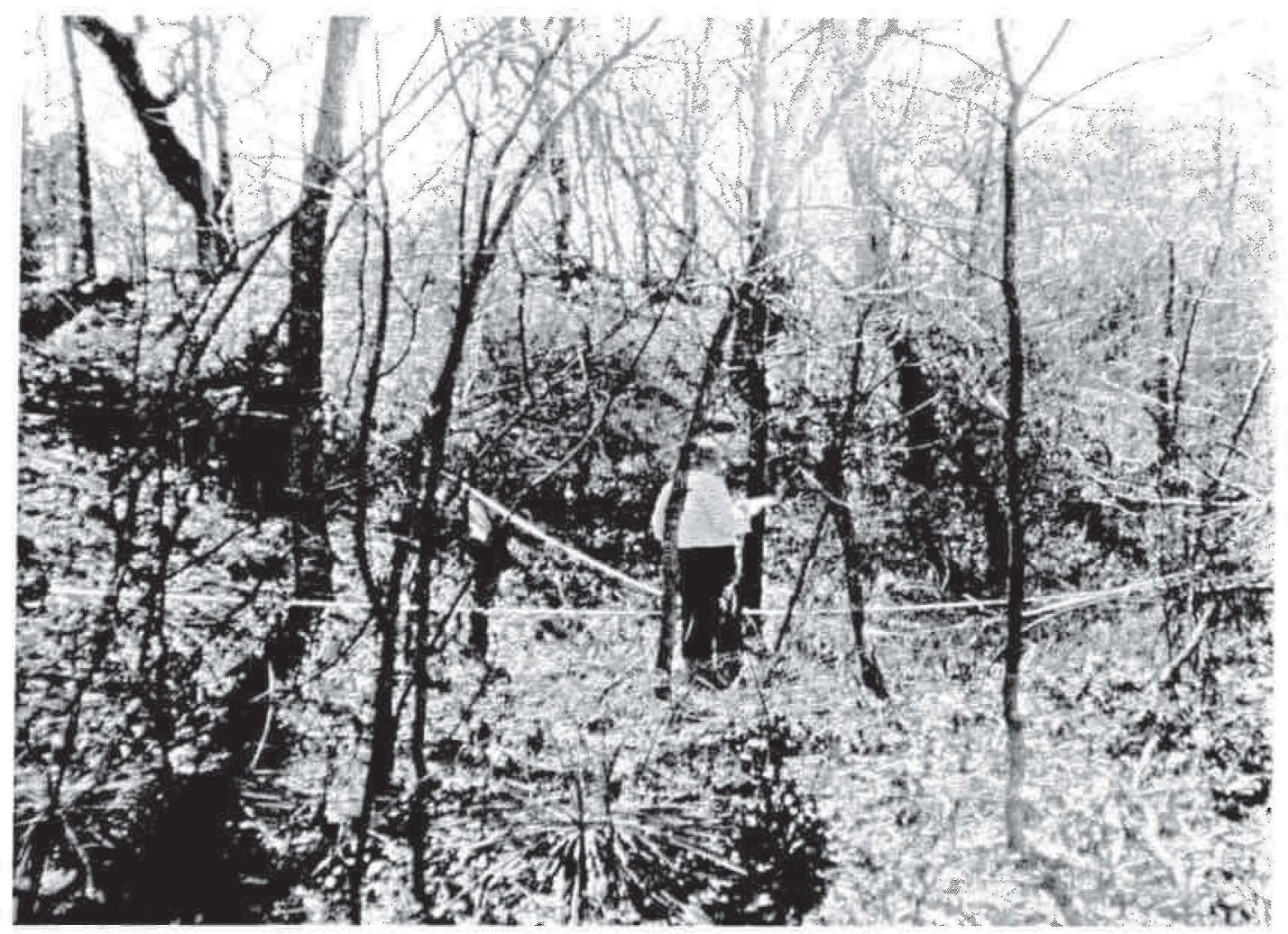

Figure 8. Mapping quarry pit F-3, facing southwest (AAS/HSU slide 10427).

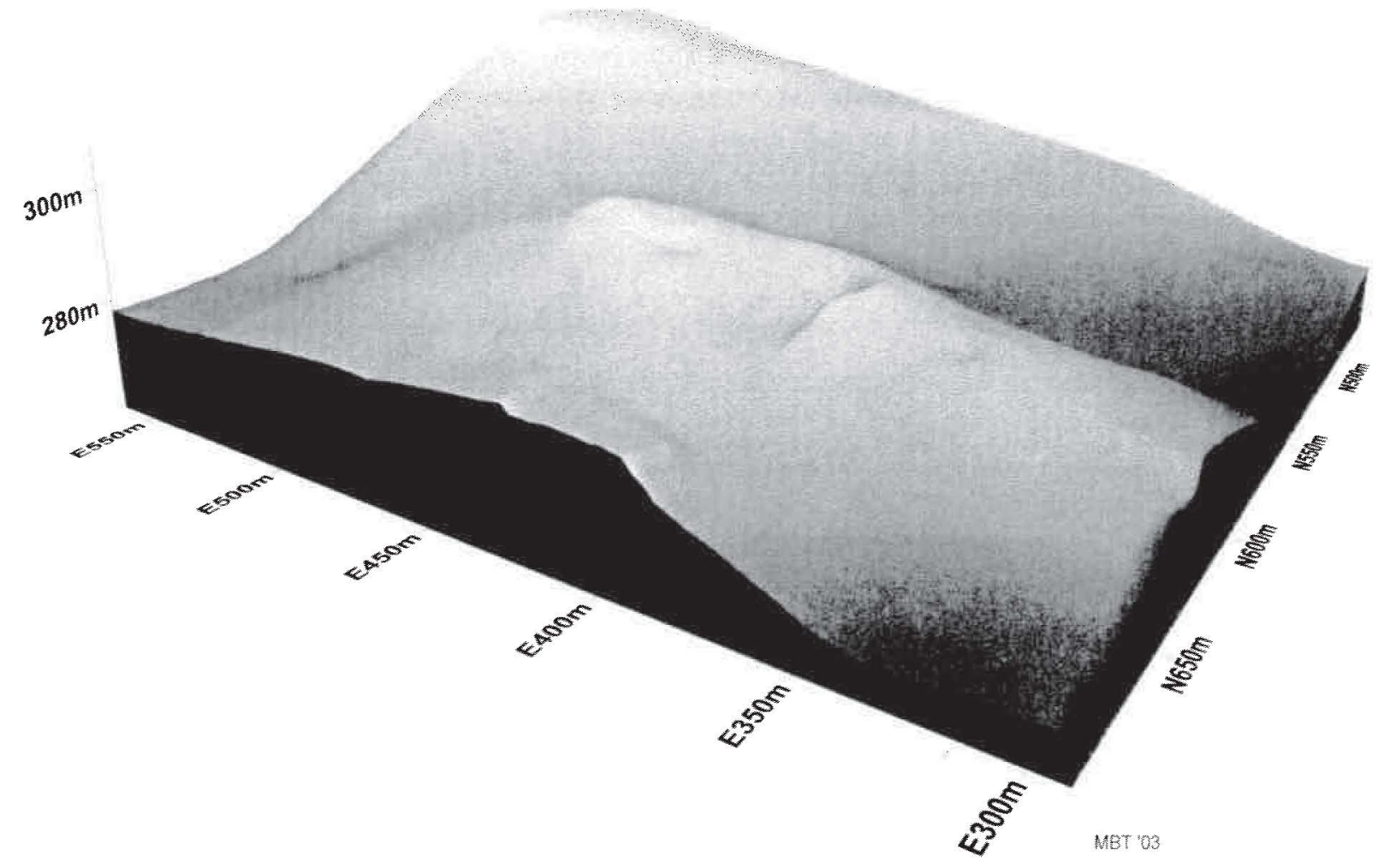

Figure 9. Thee-dimensional view of the heavily-quathed northem ridge at 3 GA22. view towards southeast. 
Mapping of novaculite quarry sites is an important first step in understanding the size and scale of these sites and the types of extraction techniques used that resulted in features of different types observable on the surfaces. Presumably the objective was similar from quarry to quarry - to expose high quality novaculite and extract it from the surrounding rock or soil - but the situation differed within and between mountains and left behind differing surface alterations.

It is clear that novaculite quarrying for toolstone was done by Caddos and their ancestors, and perhaps other Indian groups as well, over a period of thousands of years. One of the ongoing research problems is dating the period(s) of quarry use. Diagnostic artifacts found elsewhere indicate that novaculite was the favored raw material for chipped stone tools for most of the long prehistoric sequence in this region. It is not clear, however, whether quarrying was actively done at outcrops throughout this time span, or whether riverbed cobble sources or talus or surface pieces were used during specific time periods. If novaculite from outcrop quarries was exchanged beyond the local area, there remains the question of whether local people obtained and then traded it or whether outside groups came to get their own supplies directly.

Surface diagnostics at quarry sites are few, especially after collecting by visitors over the last two hundred years. Excavations of quarry features and workshop areas may produce diagnostic artifacts and/or samples suitable for dating, but sampling strategies for excavation and analysis must be developed to deal with the large amounts of artifacts uncovered (e.g.. Torrence 1984). In general, few finished tools are expected at most quarry sites, compared with the quantities of quarrying and chipping debris.

Unlike most other North American cherts or flints, novaculite has continued to be quarried or mined into the modern era. Quarrying novaculite for whetstones began in the early 1800 s around Hot Springs, and has continued, along with other commercial uses, through the twentieth century. Quarry sites (including 3GA22) show evidence of use by both Euro-Americans and Indians in different time periods, and the more recent rock quarrying may have obliterated older portions of this and other sites. Distinguishing older quarry features from the more recent ones could be done by examining debris, since distinctive tools and technologies were used by toolstone quarrying versus whetstone mining. While angular pieces of novaculite debris characterize the bulk of the natural talus and the cultural waste piles in and around quarry pits and outcrops. close examination may expose hammerstones and identifiable flakes versus metal tools, drill marks for black powder charges, or distinctive whetstone debris (although this may not be so straightforward; see Martin [1982:120] for a cautionary tale of "flakes" resulting from modern tools used to test stone quality prior to whetstone quarrying).

Numerous novaculite quarries are preserved on U.S. Forest Service and National Park Service lands. Using both old and new field techniques to document these sites has benefits both for researching novaculite tool production and exchange systems and for interpretation of these historical resources for the public. While there are many logistical problems, the potential for learning about past lifeways is significant. Specific research areas include sourcing studies to tie novaculite artifacts to their source quarries: investigation of quarrying tools and techniques; analysis of the byproducts of novaculite tool manufacture at quarries, workshops, and habitation sites to understand the spatial and social organization of production: analyzing the distribution of novaculte tools to interpret the mechanisms for novaculite exchange; and investigating the people involved in these activities as both producers" and consumers' (Trubitt et al. 2004). Novaculite quarries are but one part of the tool production and exchange systems. When novaculite quarrying is conceptualized as part of these larger cultural systems, we can shift focus from artifacts to the people who made and used these tools. The spatial distributions of novaculite antifacts show in a material form the relationships between groups of people in the past. and the interactions between people on a regional and inter-regional scale. 


\section{References Cited}

Baher, C.M

1974 A Study of Aboriginal Novaculite Exploitation in the Ouachita Mountains of South-Central Arkansas. Master's thesis, Department of Anthropology. University of Arkamsas. Fayelteville.

1982 A Brid Study of the Arkansas Novaculte Quaries. In Fancy Hill Archeological Studies in the Southern Ouachita Mountains. edited by A. M. Early and W. F. Limp, pp. 307-334. Research Series No. 16. Arkansas Archeological Survey. Fayetteville.

Bennet, W. J., Jr, with contributions from B. Bumett. C. Clark, A. F. Getys, R. Hollaway. M. Marks, J. Miller, L. Smith. J. B. Sollberger. R. Stewart, and J. Watkins

1986 Investigations at 3 HS28, the Jones Mill Site. Report No. 25. Archeological Assessments, Inc., Nashville. Arkansas.

Blaever, $\mathrm{M}$.

1995 Proposed National Register Nomination for Indian Mountain Quarry (3GA22), Hot Springs, Garland County. Arkansas Ms, on the, Hot Springs National Park, Hoi Springs, Arkansas.

Coleman. R. E.

2003 Novaculie Acquisition and Use at Litle Missouri Falls: An Early Middle Archatc Site in Montgomery County, Arkansas. The Arkansas Archeologist 42:15-43.

Coleman, R., P. S. Gardner, J. Hilliard, M. A. Pfeiffer. and J. Stewan

1999 Excavations in the Shady Lake Recreation Area and Vicinity, 1992-1993. Ouachita National Forest. The Arkansas Archeologist $38: 1-54$.

Coleman, R. E., R. Graham, C. Hill. T. Mckay, and B. Morphew

2000 Archeological Assessment for Comparments 95-97, Little Missouri Watershed. Caddo Ranger District, Ouachita National Forest, Montgomery County, Arkansas. Ouachita Cultural Resources Report No. 187. USDA Forest Service. Ouachita National Forest. Hot Springs, Arkansds.

Early, A. M.

1988 Standridge: Caddoan Settement in a Mountain Environment. Research Series No. 29. Arkansas Archeological Survey, Fayetieville.

Eichieson. M.

1997 Prehistoric Novaculite Quarties in the Ouachita Mountains. Paper presented at the Annual Meeting of the Society for American Archaeology. Nashville, Temessee, April 3. 1997. Web published at htp:/www. fs. fed.us/oonf/history/nova/ novaculte.hem.

Featherstonhaugh, G. W.

1968 (1844) Excursion through the Slave States, from Washington on the Potomac to the Frontier of Mexico; with Sketches of Popular Manners and Geological Notices. Originally published in 1844 by Harper \& Brothers, reprint edition in 1968 by Negro Universities Press. Greenwood Publishing. New York.

Flenniken. I. J. and E. G. Gamison

1975 Thermally Altered Novaculite and Stone Tool Manufacturing Techniques. Joumal of Field Archateology 2:125-131.

Griswold, L. S.

1892 Amual Report of the Geological Survey of Arkansas for 1890. Volume 11. Whotstones and the Novaculites of Arkansas. Press Printing Co.. Little Rock. Arkansas,

Hatch, J. W.

1994 The Struture and Antiquity of Prehistoric Jasper Quarries in the Reading Prongs. Pennsylvania. Journal of Middle Allantic Archacology 10:23-47.

Hemminges, E.T.

1982 Human Adaptation, in the Grand Marais Lowland. Research Series No. 17. Arkansas Archeological Survey. Fayette ville. 
Hilliard, J. E.

1995 A Preliminary Report on 3PL349, a Novaculite Quarry Site near the Shady Lake Recreation Area, Polk County, Arkansas. In Archeological Investigations in the Southern Ouachita Mountains: Excavations at the Shady Lake Recreation Area and Vicinity, by J. H. Stewart. R. E. Coleman, J. E. Hilliard, M. A. Pfeiffer, M. Etchieson, C. R. Ewen, B. Williams, and P. S. Gardner, pp. 67 72. Projeet 856 Final Report. Arkansas Archeological Survey, Fayetteville.

Holbroook, D. F. and C. G. Stone

1979 Arkansas Novaculite - A Silica Resource. Arkansas Geological Commission, Litue Rock. Reprinted from 13 th Amual Forum on the Geology of Industrial Minerals, Oklahoma Geological Survey Circular 79, 1978.

Holmes, W. H.

1891 Aboriginal Novaculite Quarries in Garland County, Arkansas. Anerican Anthropologist 4 (old series):313-316.

1974 Handbook of Aboriginal American Antiquities, Part 1, Introductory, The Lithic Industries. Originally published in 1919 as Smithsonian Institution, Bureau of American Ethology, Bulletin 60, Washington, D.C., reprinted in 1974, Burt Franklin, New York City.

Jenney, W. P.

1891 Ancient Novaculite Mines near Magnet Cove, Hot Springs County, Arkansas. American Anthropologist 4 (old series):316318.

Jeter, M. D. and H. E. Jackson

1994 Poverty Point Extraction and Exchange: The Arkansas Lithic Connection. Louisiana Archaeology 21:133-206.

Keller, W. D., C. G. Stone, and A. L. Hoersch

1985 Textures of Paleozoic chert and novaculite in the Ouachita Mountains of Arkansas and Oklahoma and their geological significance. Geological Society of America Bulletin 96:1353-1363.

Kelley, D. B.

1984 Lithic Resource Utilization in the Felsenthal Region. In Archaeology and Paleogeography of the Upper Felsenthal Region: Cultural Resource Investigations in the Calion Navigation Pool, South-Central Arkansas, edited by R. A. Weinstein and D. B. Kelley, pp. 585-589. Report submitted to the U.S. Amy Corps of Engineers, Vicksburg District, by Coastal Environments, Inc., Baton Rouge, Louisiana.

Lemley, H.J.

1942 Prehistoric Novaculite Quarries of Arkansas. Bulletin of the Texas Archeological and Paleontological Society 14.32 37.

Luedtke, B. E.

1992 An Archaeologist's Guide to Chert and Flint. Archaeological Research Tools 7. University of California Institute of Archaeology, Los Angeles.

Martin, W. A, with contributions by A. M. Early and B. Watkins

1982 An Intensive Archeological Survey of a Barite Mining District in Montgonery County, Arkansas. In Fancy Hill: Archeological Studies in the Southern Ouachita Mountans, edited by A. M. Early and W. F. Limp, pp. 1-182. Research Series No. 16. Arkansas Archeological Survey, Fayetteville.

Perino, $G$, and W. J. Bennett, J

1978 Archaeological Investigations at the Mahaffey Site, CH-1, Hugo Reservorr, Choctaw County, Oklahoma. Report for U.S. Army Corps of Engineers, Tulsa District, by the Museum of the Red River, Idabel, Okbhoma.

Pertulula, T. K.

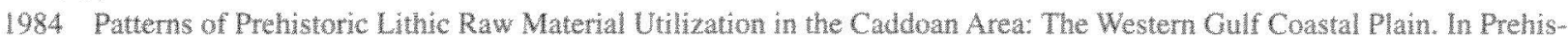
toric Chert Explotation: Studies from the Midcontinent, edted by B. M. Butlew and E. E. May, pp. 129.148. Occasional Paper No. 2. Center for Archaeological Investigations, Southert Ininois University, Carbondale.

Sargent, F. V.

1966 Indian Sites along the Ouachita River. The Record (Garland County Historical Soctery Year Book), Vol. VI, pp. 7-11, Hot Springs, Arkansas. 
Schambath. F. F.

1998 Pre-Caddoan Cultures in the Trans-Mississippi South. Research Series 53. Arkansas Archeological Survey. Fayetteville.

Steurt. C. T., D. F. Hobrook, and C. G. Stone

1984 Arkansas Novaculite: Indans. Whotslones. Plastics, and Beyond. In Proceedings of the 19th Forum on the Geology of Industrial Minerals. Ontario Geological Survey Miscellaneous Paper 114:156-167.

Torrence. R.

1984 Monopoly or Direct Access? Industrial Organization at the Melos Obsidian Quarries. In Prehistoric Quarries and Lithic Production, edited by J. E. Ericson and B. A. Purdy, pp. 49-64. Cambridge University Press. Cambridge.

Trubit, M. B.

2003 Archeological Mapping at a Novaculite Quarry Site (3GA22) in Hot Springs National Park. Limited distribution report submitted to the National Park Service (ARPA Permit No. MWR-02-1) by the Arkansas Archeological Survey. Henderson State University Research Station, Arkadelphia, Arkansas.

Trubitt, M. B., T. Green, and A. Early

2004 A Research Design for Investigating Novaculite Quarry Sites in the Ouachita Mountains. The Arkansas Archeologist $43: 17-62$.

Waddell, D. B. and K. A. King

1990 The Other Attifacts from the Bangs Slough Site. In Coles Creek and Mississippi Period Foragers in the Felsenthal Region of the Lower Mississippi Valley: Evidence from the Bangs Slough Site, Southeast Arkansas, edited by F. F. Schambach, pp. 63-84. Research Series No. 39. Arkansas Archeological Survey, Fayetteville.

Waddell. D. B. and E. Z. Waddell

1992 An Archeological Survey of 7,985 acres in the Winona, Womble, Caddo, Mena, Kiamichi, and Choctaw Districts of the Ouachita National Forest, Arkansas and OkJahoma. Project Repon No. 41. SPEARS, Inc., West Fork, Arkansas.

Waddell, D. B., E. Z. Waddell, K. Hoffman, M. Hughes, and A. Moerbe

1995 An Archeological Survey of 8,939 Acres in the Caddo Cold Springs, Fourche, Jessieville. Winona, and Womble Districts of the Ouachita National Forest, Garland, Hot Spring, Montgomery. Perry, Scott and Yell Counties in Arkansas. Project Report No, 66. SPEARS, Inc., West Fork, Arkansas.

Whittington, D. B.

1969 Arkansas' Oldest Industry. Arkansas Historical Quarterly 28:223-230.

Williams, G. 1.. M. B. Reed, L. E. Abbott, and J. W. Joseph

1993 An Archeological Survey of 7,741 Acres in the Caddo. Cold Springs, Fourche, Poteau. and Womble Districts of the Ouachita National Forest, Scott, Yell, Garland, and Montgomery Counties, Arkansas. Technical Report 147. New South Associates, Stone Mountain, Georgia.

Wyckoff. D. G.

1968 The Beaver Site and Archaeology of the Broken Bow Reservoir Area, McCurtain County. Oklahoma. Archaeological Site Repont No. 9. Oklahoma River Basin Survey, University of Oklahoma Research Institute. Norman. 